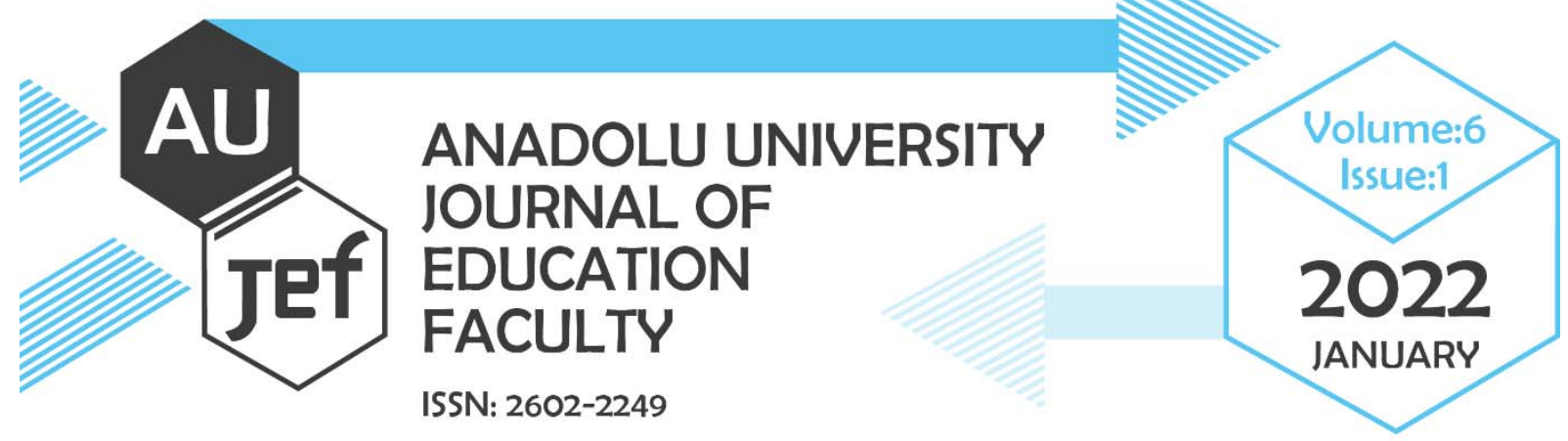

Türkiye’deki Devlet Okullarında Pandemi Döneminde Dil Öğretiminde Dijital Gereçlerin Öğrenme Desteği Olarak Kullanımı

\title{
The Use of Digital Tools Scaffolding Language Teaching During Pandemic Outbreak of Covid 19 at State Schools in Turkey
}

\section{Ümit ÖZKANAL ${ }^{1}$}

Article Type: Research Article

Application Date: 29.12.2021

Accepted Date: 04.02 .2022

To Cite This Article: Özkanal, Ü.(2022). The Use of Digital Tools Scaffolding Language Teaching During Pandemic Outbreak of COVID 19 at State Schools in Turkey. Anadolu Üniversitesi Ĕgitim Fakültesi Dergisi (AUJEF), 6(1), 17-30.

ÖZ: Bu çalışmanın amacı pandemi döneminde dil eğitimini desteklemek için hangi dijital araçların kullanıldığını araştırmaktır. K12 sınıflarında kullanılan dijital araçların araştırılmasının yanı sıra dil eğitimi dinamiklerini desteklemek için bu araçların fonkiyonlarının ne olduğu ve bu araçların kullanılma gerekçeleri de incelenmiştir. Çalışma nitel araştırma yöntemini benimseyen betimsel bir çalışmadır. Nesnel gözlem verilerini elde etmek için farklı K12 okullarında öğretmenlik uygulaması dersine katılan 43 hizmet öncesi öğretmen adayı çalışmaya katılmış, aday öğretmenlerin yansıtıcı gözlemleri temel alınarak hangi dijital araçların niçin kullanıldığı ve bu araçların ne denli etkili olduğu incelenmiştir. Nitel analiz sonucu öğretmenlerin çevrimiçi dersler sırasında farklı dijital araçları kullandığını, öğrenci katılımını arttırmak ve hedef dile yönelik etkileşimli etkinlikler ortaya koymak için farklı araçları kullanıklarını göstermiştir. Sonuç olarak, bu tür araçların kullanımıyla derslerin daha etkin, eğlenceli ve etkileşimli olduğu belirtilmiştir.

Anahtar sözcükler: Çevrimiçi Dil Öğretimi, Dijital Araçlar.

\begin{abstract}
The study aims to investigate what digital tools were used to scaffold language teaching during the pandemic outbreak of Covid-19. In addition to the list of the digital tools used at K12 classrooms, the reasons to use these tools were examined to discuss their functions to scaffold language teaching dynamics. This study was designed as a descriptive study adopting a qualitative research method. To obtain objective observation data, 43 pre-service teachers attending teaching practice at different $\mathrm{K} 12$ schools participated in the study and their reflective observations regarding which digital tools they used, how and why they used them were analyzed. The qualitative analysis indicated that the teachers used different digital tools during online lessons and they varied the tools to increase student involvement and to offer extra interactive activities to revise the target structure. Utilizing these tools and implementations, their lessons were reported as more effective, fun and interactive.
\end{abstract}

Keywords: Online language teaching, Digital Tools

\footnotetext{
${ }^{1}$ Assistant Prof. Dr., Eskişehir Osmangazi Üniversitesi, ozkanal@gmail.com orcid:0000-0003-2027-1337
} 


\section{INTRODUCTION}

The need for learning a foreign language has always been on the agenda for many people around the world. Especially with the developing technology in all areas of life and travelling opportunities thanks to technology, in the globalizing world, the number of people who want to learn one or more language(s) has been increasing.

Today, the most widely used foreign language is English: Therefore, English teaching programs are more common than all the other language teaching programs. Balla (2017) for example, states that teaching English is necessary not only for academic purposes but also for other purposes like communication, business, leisure time, reading, listening in English. Similarly, Wekke, Yandra \& Hamuddin (2017) assert that the English language is very important in communication and it is used in the whole world.

The purpose of learning a foreign language is to equip oneself with language learning skills, namely, listening, speaking, reading and writing. The techniques and methods to teach and learn a foreign language have changed through time by the changing world. Besides the techniques and methods, the teaching and learning environments have also gone through the process of change. The majority of people learn a foreign language at schools but with the developing technology, the teaching and learning environments have gone beyond schools.

The way how a language is taught has changed over time. Bates (2015) depicts this by giving examples from ancient Greek till today and states that in ancient Greece people used oral communication to teach and memorisation was important for them since they believed that memorisation would increase their brain capacity. He adds that at the beginning of the 18th century, the first blackboards appeared and they were first used in the USA. There was a fast change in everything in life and of course in education. The necessity to educate the majority of the population emerged and as a result of this in 1858, the University of London started its first formal correspondence degree via letters. While the blackboards were still in use, in the mid $20^{\text {th }}$ century, during World War II, projectors came into use for education. Bates (2015) expresses that during that time telephone communication was highly developed but this was not used for education by schools just because of its high cost.

What should not be forgotten as to the use of technology in education is the BBC- British Broadcasting Channel which provided educational radio programs for schools in the 1920s and then television programmes mixed with radio programmes. Although it was an attempt to reach large populations, it was still not very possible to reach everybody because of some deficiencies in electricity and technology access and even worse there was some resistance from teachers who were not very skilful in the use of technology (Bates, 2015).

As of the late $90 \mathrm{~s}$ and beginning 2000s, the development of the Internet and the emergence of interactive social media helped education in depth. The emergence of Facebook, Youtube, Twitter, Podcast and Whatsapp etc. and the fact that they were available all over the world resulted in a kind of incorporation of formal education with these applications and social media. Both teachers and students began to use them for educational purposes as supporting materials at first. It can be expressed that at first the use of social media in education was not in formal education in general but as supportive and additional materials to the subjects (Bates, 2015).

The emergence and use of modern technology and social media applications in teaching and learning English have also affected language classrooms. Schools have started to design their classrooms based on this and interaction between teachers and students has started to go beyond school walls. The 
fact that English language has become so popular all over the world has also influenced the use of media technology in and out of the classroom and the integration of media and related applications in English language teaching and learning has come to the agenda of English education at almost all levels.

Technology integration into language learning and teaching yields many opportunities and enables flexibility in any condition. Distance, time, limited resources, differences in learning and teaching processes, popular trends, economic or social variabilities, global incidents can be managed with the help of effective and appropriate technology integration and digital tools. The most striking incident is the global health crisis caused by the pandemic outbreak of COVID-19. The outbreak of Covid -19 pandemic led to dramatic changes in language teaching. As a result of school closure during the pandemic, most teachers in the world have been forced to apply online teaching integrating different digital tools. For many teachers; the use of digital tools in language teaching was a completely new experience. Besides, most language teachers do not know what and how to use them effectively. Thus, observing and researching the use of digital tools during online teaching due to pandemic outbreak has become an urgent research topic to address (Moorhose and Kohnke, 2021). In this vein, this study aims to investigate the use of digital tools scaffolding language teaching in Turkey to gain insights of technology integration and its benefits to compensate for any learning difficulties and inequalities due to unconvertible constraints.

The integration of technology in the area of English teaching and learning has played and still plays a positive role for both teachers and students of English. For example, Pun (2013) expresses that teachers using them in and out of the classrooms may provide better, more enjoyable and more motivating situations for students. Pun (2013) also adds that since they are almost available for many people, these tools and applications should be used in language classrooms soon because of their efficiency in motivating and stimulating success in learning and teaching English. Similarly, Akayoğlu et al (2020) claim that in many language programs, having developed digital skills is one of the goals in English teaching and learning and they define digital literacy as the ability to use these technologies correctly and properly and positively for different educational objectives.

When mentioning these technologies and applications, it may be correct to state that Web 2.0 technologies are of great importance since they let users communicate, share information, interact with each other, share photographs and videos and related visuals, create contents and share them etc. It is claimed that Web 2.0 tools enhance the fluency of students in listening and speaking, and also help them correct their pronunciation and improve their vocabulary (Özel, 2013). Another useful purpose of using these tools may be expressed in that they help students check and follow their learning based on their needs and learning speed (Thomas, 2009). Similarly, the related literature asserts that there are many positive results of using Web 2.0 in language learning since Web 2.0 tools help learners improve their attitudes, motivation, their willingness to learn and objectives and provide some benefits on the language skills (Barrot, 2016; Grant, 2016). On the other hand, Çobanoğlu and Yücel (2017) put forward that one of the most important elements of using these tools in learning and teaching environments effectively is the attitude of the learner/user towards the Web 2.0 tools. Therefore, it may be concluded that when these tools are taken into consideration to use in teaching and learning environments, the attitudes of the students towards Web 2.0 tools should also be taken into consideration. It is possible to state that most students have a positive attitude towards Web 2.0 tools because they have been equipped with technology since they were born. Web 2.0 tools are known to help interaction between teacher-learner and learnerlearner and thus create much richer and more enjoyable education environments (Cochrane, 2014). That learners can share multimedia, tag and mark social pages enables them to create richer and better learning 
processes (Albayrak and Kıyıc1, 2017). Kiz1l (2015) states that studies carried out on the effects of Web 2.0 tools in language learning show that these tools have a positive effect on students' attitudes about foreign language learning since the tools facilitate and accelerate foreign language learning. In a study carried out by Wang and Vasquez (2012), it was found out that Web 2.0 tools were very useful in improving students' writing skills.

Aşıssoy (2018) expresses that the effects of Web 2.0 tools on education have been studied and it has been found out that there are many advantages of using Web 2.0 tools for students who use them in their learning. Some studies and findings on the topic may be stated as follows: Lu, Lai, \& Law (2010) have found out that the Web 2.0 tools promote learners to become technology literate, active and participating individuals, and doing so students may be ready for life in a much better and equipped way. The findings of Barbara and Linda (2013) depict that Web 2.0 tools provide interactive environments and students have a chance to collaborate with others in different environments for learning. Cochrane (2014) touches on a different topic by stating that students work with the tools actively and productively and the results of what they have been doing are clear and tactual thanks to the Web 2.0 tools. He also puts forward that using Web 2.0 tools in learning lets them develop cognitively since they use almost all their sensory organs in dealing with learning (Cochrane, 2014). In accordance with the findings above, Huffman (2017) states that using Web 2.0 tools changes the learners from being passive to active since they do not consume the information solely but also create, examine, analyze and put forward new information. As seen from the studies above, it can be said that Web 2.0 tools have created a new information and teaching-learning era and learners of all subjects have started to become actively involved in learning.

The developing technology and Web 2.0 tools, at first, have been used in teaching-learning processes as the subsidiary element in educational settings but with the emergence of the Covid 19 pandemic, since the beginning of 2020, everything has changed dramatically and these tools and technology related to them have become the sole educational tools and applications. The classical face to face face, in classroom learning activities, were replaced with the new methods that many teachers and learners were not ready or used to.

The institutions all over the world had to take precautions to keep education going during the pandemic outbreak and they tried to create some new ways to deliver education at all levels. Not only in Turkey but all over the world at all educational levels, all schools including universities had to shift conventional education to new online education using technology and Web 2.0 tools. This shift has also brought some advantages and disadvantages to the delivery of online courses. It may be expressed that the most important feature of online education is that it is flexible and convenient for both teachers and students since there is not limitation of time and location (Bower, et. al, 2015). As to disadvantages, it can be stated that this new and sudden teaching-learning system has created a kind of anxiety for both teachers and students. Poor internet connection and inappropriate study conditions at home have created problems especially for students and teachers as well (Kapasia, et al., 2020). The lack of face to face interaction and the need for explanation is so weak via online education has made it difficult for students (Simamore, 2020). It is possible to state that students have lost their interest to learn because of these problems they have faced (Lestiyanawati, 2020). Sari and Nayır (2020) point out another aspect by expressing that the students do not have enough knowledge and experience on online education, they may have problems in terms of technological support and experience on distance education.

Sari and Nayır (2020) also mention that since schools were closed in many countries, OECD looked for some technological solutions to keep teaching and learning during the pandemic. In the 
Turkish context, the Turkish Ministry of National Education started distance education via a network called Educational Information Network (EBA) for all levels of schools. By taking into consideration that all students did not have the opportunity to reach distance education using the internet, the Ministry also allocated 6 television channels for distance education (MoNE, 2020). Similarly, the Council of Higher Education - CoHE- (2020) made a similar decision for the education of university students and legal arrangements were made for them to pursue their education online. Apart from that CoHE (2020) also allowed students to suspend their studies if they wanted to do so since reaching online education might be difficult for them.

The study aims to investigate what digital tools were used to scaffold language teaching during the pandemic outbreak of COVID-19. In addition to the list of the digital tools used at K12 classrooms, the reasons to use these tools were examined to discuss their functions to scaffold language teaching dynamics. For this purpose, the following questions were discussed:

1. What digital tools are used to scaffold language teaching during the pandemic outbreak of COVID-19?

2. What are the reasons to use these tools?

3. Are these online tools effective in language teaching?

\section{METHOD}

\subsection{Research Design}

This study was designed as a descriptive study adopting a qualitative research method. The descriptive research approach is a basic research method that examines the situation, as it exists in its current state. Descriptive research involves the identification of attributes of a particular phenomenon based on an observational principle or the exploration of the correlation between two or more phenomena (Kumar, 2011). Qualitative descriptive studies are based on naturalistic inquiry studying something in its natural state to the extent that it is possible within the context of the research. Since the qualitative descriptive studies focus on discovering the nature of the specific events under study, data collection involves moderate, structured, open-ended, individual or focus group interviews. However, data collection also may include observations, and examination of records, reports, photographs, and documents (Lambert \& Lambert, 2021).

\subsection{Context of the Study}

Due to the rapid spread of the Covid 19 pandemic, the schools at all education levels were closed in March 2020. During school closure, online education was started and defined as emergent remote teaching. Different from various online platforms offered for education in the world, the EBA (Education Information Network) has been launched and used officially as an online platform in the distance education model at K12 schools in Turkey. However, significant infrastructure and technological problems were reported in the EBA system (e.g. Doğan \& Koçak, 2020), thus many teachers tried and utilized different online platforms and digital tools to maintain teaching and learning processes.

In the same way, the universities offered different learning management systems for theoretical and practical courses during distance education during the pandemic outbreak. Particularly for education faculties, teaching practice (i.e. practicum) courses were conducted in association with distance 
education systems at K12 schools. Pre-service teachers attended online courses at EBA and/or Zoom platforms offered by the schools.

Within the context of this study, the pre-service language teachers working at state schools at different language levels, namely primary, secondary and high schools were selected as participants. They participated in online lessons as observers and they did their teaching practice online as well. The online language lessons that the participant teachers attended were under research focus. The participant teachers observed and reported what digital tools their mentors used in online lessons and they evaluated the effectiveness of these tools as an objective stakeholder of the teaching and learning process.

\subsection{Data Collection Tool}

For the data collection tool, a reflection task written by pre-service teachers was utilized. In this reflection task, the participants were asked to elaborate on their observations about what digital tools were used at online language classes, why they were used, and how effective they were. The participants were asked to complete a table consisting of three main questions: the name and the URL address of the Web 2.0 tool, how it was utilized for language teaching purposes by the observed mentor teacher, and if the tool was effective or not. While completing this task, the prospective teachers were expected to provide detailed examples and specific cases where the tools were employed. For example, after providing the name and the link of the Web 2.0 tool, in the second column, the participants provided the reasons for using the mentioned tool (assessment, teaching, giving homework, etc.). Afterwards, in the third column, the pre-service teachers wrote their opinions about the effectiveness of the tool for the mentioned use. In this final column, they provided details about the utilization of the tool and how they evaluated this use. The participants were asked to write at least five Web 2.0 tools that the mentor teacher was using during the observed online English lessons.

\subsection{Participants}

Applying convenient sampling, 43 fourth-year university students who were studying to become EFL teachers were selected as the participants of the study. They were taking the Teaching Practice course as part of their practicum program and they were working with three different university supervisors. There were 30 female and 13 male pre-service teachers involved in this study. As part of their Teaching Practice course, the participants attended two different high schools $(n=28)$ and a secondary school $(n=15)$. Overall, the prospective teachers observed 8 high school and 3 secondary school mentors.

\subsection{Data Analysis}

For the data analysis of the study, the reflection tasks of the participants were examined, collated and coded. Since the purpose of the study is to determine the type of Web 2.0 tools that the mentor teachers utilize in their online English lessons, the qualitative data were coded and categorized. Upon analysis, the type of Web 2.0 tools, the purpose of using them, and the evaluations of the participants were identified and grouped for further analysis. The tools appearing less than 3 times were excluded from the analysis. For intercoder reliability, the researcher worked with an expert from the field. Each coder analyzed a randomly selected portion (20\%) of the data to ensure intercoder reliability (O' Connor 
\& Joffe, 2020). Once the coding procedure was completed, the agreement rate between the coders was calculated. The results showed a relatively high agreement rate between the two coders $(86,4 \%)$.

\section{FINDINGS}

The data analysis revealed that the most commonly used Web 2.0 tools were the application of the coursebook, EBA, Kahoot, Mentimeter, Oxford Learners' Bookshelf, Padlet, Quizziz, Socrative, Youtube and Zoom. This section will explore the findings of each tool in detail.

A summary of the results of the study can be found in Table 1 below. Accordingly, the most frequently mentioned Web 2.0 tool was Zoom $(n=34)$ followed by Kahoot $(n=20)$. These two tools were employed for several different purposes in online English classes. Another tool was Youtube ( $n=9)$. It is a widely recognized video database and the results revealed that the teachers made use of it in their lesson for practising the target language and delivering their lessons. The participants also pointed out that the observed in-service teachers were utilizing the application of the coursebook $(n=5)$ during the online English classes. Other Web 2.0 tools used in English classes were mentioned by three participants. Almost all of the mentioned tools were employed for practising and revising the target language forms while a few of them were integrated for delivering the language instruction.

Table 1: Summary of the findings

\begin{tabular}{|c|c|c|c|}
\hline Web 2.0 Tool & Frequency & The purpose of Use & Evaluation \\
\hline Zoom & 34 & $\begin{array}{l}\text { Practising \& revising TL } \\
\text { Delivering instruction } \\
\text { Checking homework } \\
\text { Giving feedback }\end{array}$ & $\begin{array}{l}\text { Useful, easy to use, enables } \\
\text { variety, helpful, and effective } \\
\text { but not for group work and } \\
\text { teaching writing }\end{array}$ \\
\hline Kahoot & 20 & Practising \& revising TL & $\begin{array}{l}\text { Amusing, fun, practical and } \\
\text { effective }\end{array}$ \\
\hline Youtube & 9 & $\begin{array}{l}\text { Practising \& revising TL } \\
\text { Delivering instruction }\end{array}$ & Fun, good, helpful and practical \\
\hline Coursebook Application & 5 & Delivering instruction & Fun, useful, and interactive \\
\hline $\mathbf{E B A}$ & 3 & $\begin{array}{l}\text { Practising TL } \\
\text { Delivering instruction }\end{array}$ & $\begin{array}{l}\text { Good for students but it has } \\
\text { layout and connectivity } \\
\text { problems }\end{array}$ \\
\hline Mentimeter & 3 & $\begin{array}{l}\text { Practising TL } \\
\text { Brainstorming }\end{array}$ & Handy and effective \\
\hline Oxford Learners' Bookshelf & 3 & $\begin{array}{l}\text { Practising TL } \\
\text { Delivering instruction }\end{array}$ & Enables variety and effective \\
\hline Padlet & 3 & $\begin{array}{l}\text { Practising TL } \\
\text { Assigning homework }\end{array}$ & Productive and effective \\
\hline Quizziz & 3 & Practising \& revising TL & Fun, practical and interactive \\
\hline Socrative & 3 & Practising\& revising TL & Practical and useful \\
\hline
\end{tabular}




\subsection{Zoom}

After becoming popular due to the pandemic outbreak of COVID-19, Zoom was one of the most commonly used Web 2.0 tools in the study context. The majority of the participants $(n=34)$ reported the utilization of this tool during online English lessons. The data revealed that Zoom was employed for practising and revising target language forms, delivering the lesson, checking the homework of the language learners and giving feedback. Since it is an interactive tool, the participants believe that it is useful and effective for conducting English lessons online. Thanks to the tools embedded in Zoom, the teachers can create variety in the classroom and it is easy to use. On the other hand, the prospective teachers noted that the tool was not effective for teaching and practising writing skills and that it was difficult to arrange group work activities. Nevertheless, the participants thought that it was the "best" tool for online English classes.

In my opinion, zoom is the best platform that can be used in this pandemic time and our mentor teacher uses it in all lessons. (P4)

It is useful for both the students and the teacher if the teacher continues the lesson on the zoom. because this platform is easily accessible. It is also interactive. (P42)

\subsection{Kahoot}

Being an interactive, real-time, practice tool, Kahoot was another popular Web 2.0 tool stated by the participants of the study. Nearly half of the participants $(n=20)$ indicated that this tool was being employed for practising and revising target language during online English lessons. Based on their observations was seen that the tool was practical and effective for exercising target language structures and vocabulary. They also believed that Kahoot created an amusing way for pupils to put their knowledge into practice and compete with their classmates online. As a result, they pointed out that the pupils who were not outgoing or who were not very enthusiastic could participate in Kahoot games and showed interest in the lesson.

I think this website is so impressive because students like playing games but while playing, they are learning unconsciously with fun. There is a race and they have to use all their knowledge to win. Therefore, they can see their developments in this game. (P38)

Kahoot is interactive and makes even a shy student take part in the quizzes actively. Students do not participate in the activities in the online classroom so this platform will be helpful to encourage the silent students to take part in the activities. (P11)

\subsection{Youtube}

Since Youtube is commonly used as a source for various kinds of online videos, the English teachers integrate this tool into their lessons as well. The participants $(n=9)$ wrote that Youtube was being used for practising and revising English structures and vocabulary, and for delivering the language instruction. They underlined that the tool was effective for practising and teaching listening in the target language. The teacher candidates rated the tool as fun, practical and helpful.

Youtube contains lots of different videos in different contexts. Especially for visual learners,

It is practical to study listening skills with provided visuals. Also, It is easy to access 
Youtube since you can easily share the link of the video, song, or any other activity you have found on Youtube. (P25)

\subsection{Coursebook Application}

Another Web 2.0 tool used for delivering language instruction online was the coursebook application. Fewer participants $(n=5)$ reported the use of this tool during their observations. They believed that the tool was interactive and useful for teaching English. The teacher candidates also noted that this tool could be used in both online and in face-to-face classes.

Interactive textbooks developed for the classroom environment are very useful for students both online and in face-to-face education periods because they contain materials such as active answering questions and listening activities. So, it is useful for error correction and exercising the target language. (P16)

\subsection{EBA}

The EBA (education information network) platform was one of the websites that was utilized frequently during the Covid-19 online education process. The site was issued by the Ministry of National Education in 2012, and it was used as an online platform for additional course materials. Three of the prospective teachers pointed out the use of this tool in the observed English classes for delivery and practice purposes. They noted that the tool was good for students to provide variety but it had some problems.

EBA doesn't look good in terms of its layout. In addition to this problem, it is too slow to do any activities over the website. The activities aren't prepared properly, and they lack language skills. I wouldn't want to use it during my lessons. (P37)

\subsection{Mentimeter}

Mentimeter is a web 2.0 tool that enables real-time polling and brainstorming. It was one of the fewer mentioned tools that were used in online English classes observed in the study context. The tool was utilized for brainstorming ideas and practising target language structures and vocabulary. The participants $(n=3)$ stated that Mentimeter was handy and effective in practising writing.

The use of the web tool during the writing lesson was good and effective. My suggestion is that we should use Mentimeter to engage students in the activities during online classes. (P41)

\subsection{Oxford Learners' Bookshelf}

Another online tool employed for practising the target language and delivering English instruction was Oxford Learners' Bookshelf. The tool offers ebooks and presentation software for practising English. The participants $(\mathrm{n}=3)$ deemed the tool as good for offering variety and effective for providing exercise for the learners. 
The coursebook has a variety of activities in itself. Teachers can teach a new grammar point and can give different types of vocabulary such as common phrases used in English. The exercises in the book differ from each other, especially for grammar points, from filling in the blanks to putting in order exercises. Students can improve their grammar knowledge by doing these activities. (P9)

\subsection{Padlet}

For assigning homework to the learners and practising target language forms, the participants $(n=3)$ mentioned Padlet as another web 2.0 tool. The tool presents interactive activities such as brainstorming, creating posters, and designing timelines. The prospective teachers said that the tool was productive and effective for practising writing skill.

The teacher gave homework to the students and asked them to write it on Padlet. I think it was effective for an online course. Except for that, I would use Padlet in writing lessons. I would send a link to the students and ask them to write their ideas, opinions on the screen immediately. Thus, observing students would be more effective and easy. (P17)

\subsection{Quizziz}

Another specified tool for online English classes was the Quizizz website. The tool allows teachers to create their quizzes about a topic and use the available ones. It can be used as an offline and an online tool. The participants $(n=3)$ believed that the tool was practical for exercising and revising English forms since it was interactive.

The students used the platform for revising the unit. There were 20 questions and they needed to choose the correct option. It was fun because of the time limit. When the students played the game, they were excited and focused on the questions. (P2)

\subsection{Socrative}

Lastly, the participants $(n=3)$ pointed out that during the online lessons, a few teachers were using Socrative. The tool helps teachers to administer tests and monitor students' progress. They noted that the tool was practical to employ and useful for practising and revising English structures and vocabulary.

I learned about this website from my mentor. This website is very useful for preparing tests, and quizzes. The mentor uses this website actively to give students homework and exercises.

\section{DISCUSSION and RESULT}

In this study, a different research perspective on language teaching during Covid -19 was adopted and it was aimed to reveal what type of digital tools language teachers at K12 schools in Turkey used in their online lessons and to analyze the functions and effectiveness of these tools. In this way, the question of whether this unexpected crisis and inevitable technology integration could contribute to teachers' online practices or not could be answered to some extent. 
The results indicated that the teachers used different digital tools during online lessons and they varied the tools to increase student involvement and to offer extra interactive activities to revise the target structure. Using these tools and implementations, their lessons were reported as more effective, fun and interactive. On that point, it can be claimed that the use of digital tools is the strength of online teaching and during a pandemic outbreak the teachers in this study could be evaluated as successful to implement different tools for different lesson outcomes and effectively. This result complies with Bailey and Lee's (2020) study. In their study, it was also seen that EFL teachers with experience of technology integration and digital tools benefited from online teaching processes, encountered fewer obstacles and varied their online tasks by applying different tools. Thus, it could be interpreted that the widespread use of technology in language teaching so far, as aforementioned in the literature review, provides a good advantage and familiarization for language teachers. As indicated in the result of this study, the language teachers used different tools and they could compensate for many infrastructure problems and other difficulties in that way. MacIntyre, Gregersen, and Mercer (2020) explained this as active coping strategies, using many different ways, tools to improve the situation.

The findings of which digital tools were used showed that different tools, mostly Zoom, Kahoot, Youtube were used in the classroom and these digital tools were reported as effective ways to engage students in screen sharing, chat rooms and saving options. These results were consistent with the findings of Destianingsih and Satria (2020), Hamid (2020) and Wong (2020) as teachers tend to vary the digital technologies to enrich their teaching resources and foster learning.

Furthermore, the results also pointed out that teachers varied the tasks with different aims such as revising, practising, presenting the structure and giving assignments. This result can be explained by teachers' beliefs about language teaching and cognitions about their students' needs. Pozo et al's study (2021) discussed the same finding that teachers' beliefs about teaching, online teaching and their student needs determine what teaching methods and what instructional practice they would apply.

The overall results of this study are consistent with the findings of the related studies (Pozo et al, 2021, Bailey \& Lee, 2020; Wong, 2020) that teachers became familiar with the digital tools and they practised using these tools for different aims to increase student involvement to reinforce comprehension. Thus, it can be claimed that the unexpected teaching conditions caused by the global health crisis contributed to $t$ teachers' effective use of technology in language teaching.

Lastly, it should be noted that pre-service teachers' reflections and observations were used as the databases for this study. It provided objective observations and evaluations about actual online teaching. Additionally, it was a valuable consciousness-raising for pre-service teachers to use different digital tools in language lessons. When the qualitative data collected on pre-service teachers' evaluation regarding the effectiveness of those tools is examined, it can be seen that pre-service teachers appreciated the use of different tools and they evaluated these in terms of practicality, student involvement and fun or friendly atmosphere offered. They questioned whether they would use these tools in their teaching practices. Hence, it might be stated that these evaluations could contribute to teacher education and research in a way that pre-service teachers are stakeholders in teaching processes and their observations are valuable and involvement in the research process could also scaffold their teaching competence.

As a result of the Covid-19 pandemic and widespread imperious online teaching, it is all agreed that technology is a necessity and even compulsory especially in emergent situations. Thus, teachers' competency in using technology, particularly digital tools, in their lessons becomes important day by day. Not only in case of school closures but also to scaffold face-to-face education, digital tools are 
effective ways to foster learning processes. When used in full online teaching, digital tools can be good ways to cope with any unexpected connection obstacles and student-related problems and resource constraints. Additionally, digital tools could support the teaching processes. To discuss all these arguments, the teachers' practices should be examined. In this sense, the present study focused on language teachers at K12 state schools and the digital tools used in the online language teaching during the pandemic outbreak were investigated in terms of types, aims and effectiveness from pre-service teachers' perspectives, as an objective stakeholder in this process.

The results indicated that the teachers used different digital tools in addition to the EBA platform which was launched and offered by the Ministry of Education. The teachers aimed to scaffold and improve students' learning with these tools to present (deliver instruction) the target structure more interactively and effectively, to revise and to teach the language efficiently with more fun. The results showed that language teachers were aware of different digital tools and they used them for a certain purpose in line with the learning outcomes. The evaluations of the use of the tools concerned revealed that the students and teachers had a good experience and the aims of the use of digital tools were mostly achieved.

It is believed that these results would contribute to the related literature on online language teaching and teacher education in a way that language teachers' awareness and competence to use different digital tools should be examined in actual classroom practices and teachers' practices should be examined and different variables and reasons to use digital tools could be examined more. Moreover, the results of the study revealed that language teachers' competencies to use different digital technologies should be improved. In-service training should be organized regularly to help teachers catch up with technological innovations. Teacher training programs should be revised and courses on digital technology use in language teaching should be offered. The pre-service teachers should be trained as prospective teachers knowledgeable about different digital tools. 


\section{REFERENCES}

Akayoğlu, S., Müge Satar, H., Dikilitaş, K., Cirit, N., \& Korkmazgil, S. (2020). Digital literacy practices of Turkish pre-service EFL teachers. Australasian Journal of Educational Technology, 36 (1), 85-97.

Albayrak, E., \& Kıyıcı, M. (2017). Bilgisayar ve öğretim teknolojileri eğitimi bölümü öğrencilerinin kişilik tiplerine göre web 2.0 araçlarını kullanım durumları. Turkish Journal of Computer and Mathematics Education (TURCOMAT), 8(3), 481-512.

Aşıksoy, G (2018). ELT students' attitudes and awareness towards the use of WEB 2.0 technologies for language learning students. Journal of Language and Linguistic Studies, 14(2), 240-251

Bailey, D. R., \& Lee, A. R. (2020). Learning from experience in the midst of Covid-19: Benefits, challenges, an strategies in online teaching. Computer Assisted Language Learning Electronic Journal (CALL-EJ), 21(2), 176-196.

Balla, E. (2017). English language and its importance of learning it in albanian schools. Academic Journal of Interdisciplinary Studies, 6 (2), 109 -114.

Barrot, J. (2016). Using facebook-based e-portfolio in ESL writing classrooms: impact and challenges. Language, Culture and Curriculum, 29(3), 286-301.

Bates, T. (2015). A short history of educational technology. In teaching in digital age. https://opentextbc.ca/teachinginadigitalage/chapter/section-8-1-a-short-history-ofeducational-technology/ retrieved from November 30, 2021.

Bower, M., Dalgarno, B., Kennedy, G. E., Lee, M. J., \& Kenney, J. (2015). Design and implementation factors in blended synchronous learning environments: Outcomes from a cross-case analysis. Computers \& Education, 86, 1-17.

Cochrane, T. D. (2014). Critical success factors for transforming pedagogy with mobile Web 2.0. British Journal of Educational Technology, 45(1), 65-82. https://doi.org/10.1111/j.1467- 8535.2012.01384.x

CoHE. (2020a). Saraçmade a statement on the distance education. https://www.yok.gov.tr/en/Sayfalar/news/2020/Sarac-made-a-statement-on-the-distance-education. aspx.

CoHE. (2020b). English university students allowed to suspend studies and postpone enrollment.CoHE. https://www.yok.gov.tr/en/Sayfalar/news/2020/University-Students-Allowed-to-Suspend-Studies-an PostponeEnrollment.aspx

Çobanoğlu, A, A., \&Yücel E, S. (2017). İngilizce okutmanlarının teknoloji kullanımları ve eğitimde bilgi ve iletişim teknolojilerine yönelik tutumları. Yükseköğretim ve Bilim Dergisi, 7 (3), 453-461.

Destianingsih, A., \& Satria, A. (2020). Investigating students' needs for effective English online learning during Covid-19 for Polbeng students. ELT-Lectura: Studies and Perspectives in English Language Teaching, 7(2), 147-153.

Doğan, S., \& Koçak, E. (2020). EBA sistemi bağlamında uzaktan eğitim faaliyetleri üzerine bir inceleme. Ekonomi ve Sosyal Araştırmalar Dergisi, 7(14), 110-124.

Erarslan, A. (2021). English language teaching and learning during Covid-19: A global perspective on the first year. Journal of Educational Technology \& Online Learning, 4(2), 349-367

Fatima, N. (2020). English language teaching during the times of COVID-19- challenges and opportunities: A brief study of GFP students in Muscat College. Journal for Research Scholars and Professionals of English Language Teaching, 4(21). http://www.elsevier.com/locate/scp

Gao LX and Zhang LJ (2020). Teacher learning in difficult times: examining foreign language teachers' cognitions about online teaching to tide over covid-19. Front. Psychol. 11:549653. doi: 10.3389/fpsyg.2020.549653

Grant, S. (2016). Peer review process completion rates and subsequent student perceptions within completely online versus blended modes of study. System, 62(1), 93-101.

Hamid, S. M. (2020). Online digital platforms during covid-19 in EFL classes: Visual impairment student' perception. English, Teaching, Learning, and Research Journal (ETERNAL), 6(2), 328-339. https://doi.org/10.24252/eternal.v62.2020.a10 
Huffman, K. (2017). Web 2.0: Beyond the concept practical ways to implement RSS, podcasts, and Wikis. Education Libraries, 29(1), 12-19.

Kapasia, N., Paul, P., Roy, A., Saha, J., Zaveri, A., Mallick, R. \& Chouhan, P. (2020). Impact of lockdown on learning status of undergraduate and postgraduate students during COVID-19 pandemic in West Bengal, India. Children and Youth Services Review, 116, 105-194.

Kızıl, A. Ş. (2017). Exploring EFL learners' use of web 2.0 tools: Preliminary findings. Pamukkale University Journal of Social Sciences Institute, 27, 28-40 doi:10.5505/ pausbed.2017.71602

Kumar, R. (2011). Research Methodology: A Step-by-Step Guide for Beginners. 3rd Edition. Sage, New Delhi.Lambert, V. \& Lambert, C. (2021). Qualitative descriptive research: an acceptable design. Pacific Rim International Journal of Nursing Research. 16(4), 255-256.

Lestiyanawati, R. (2020). The strategies and problems faced by Indonesian teachers in conducting e-learning during COVID-19 outbreak. Culture, Literature, Linguistics, and English Teaching, 2(1), 71- 82.

Lu, J., Lai, M., \& Law, N. (2010). Knowledge building in society 2.0: Challenges and opportunities. In: Khine M., Saleh I. (eds) New Science of Learning. New York: Springer.

MacIntyre, P. D., Gregersen, T., \& Mercer, S. (2020). Language teachers' coping strategies during the Covid-19 conversion to online teaching: Correlations with stress, wellbeing and negative emotions. System, 94, 1-13. https://doi.org/10.1016/j.system.2020.102352

MoNE. (2020). Press release by the minister on distance education https://www.meb.gov.tr/bakan-selcuk-23-marttabaslayacak-uzaktan-egitime-iliskin-detaylari-anlatti/haber/20554/tr

Moorhouse, B., L \& Kohnke, L (2021). Responses of the english language teaching community to the COVID-19 pandemic. RELC Journal, https://doi.org/10.1177/00336882211053052

O’Connor, C., \& Joffe, H. (2020). Intercoder reliability in qualitative research: debates and practical guidelines. International Journal of Qualitative Methods, 19, 1-13. https://doi.org/10.1177/1609406919899220

Özel, A. G. (2013). The use of the internet and web 2.0 tools among efl instructors, ma thesis http://acikerisim.akdeniz.edu.tr:8080/xmlui/handle/123456789/2211, retrieved from November 30, 2021.

Pozo J-I, Pérez Echeverría M-P, Cabellos B and Sánchez DL (2021). Teaching and learning in times of covid-19: uses of digital technologies during school lockdowns. Front. Psychol. 12:656776. doi: 10.3389/fpsyg.2021.656776

Pun, M. (2013). The use of multimedia technology in English language teaching: A global perspective. Crossing the border: International Journal of Interdisciplinary Studies, 1(1), 29-38.

Sari, T., \& Nayır, F. (2020). Challenges in distance education during the (Covid-19) pandemic period. Qualitative Research in Education, 9(3), 328-360. doi:10.17583/qre.2020.5872.

Simamora, R. M. (2020). The Challenges of online learning during the COVID-19 pandemic: An essay analysis of performing arts education students. Studies in Learning and Teaching, 1(2), 86-103.

Thomas, M. (2009). Handbook of research on Web 2.0 and second language learning. Hershey, PA: IGI Global Reference.

Turchi, L. B., Bondar, N. A., \& Aguilar, L. L. (2020). What really changed? Environments, instruction, and 21st century tools in emergency online English language arts teaching in United States schools during the first pandemic response. Frontiers in Education, 5, 1-13. https://doi.org/10.3389/feduc.2020.583963

Wang, S., \& Vasquez, C. (2012). Web 2.0 and second language learning: What does the research tell us? CALICO Journal, 29(3), 412-430.

Wekke, I. S., Yandra, A., \& Hamuddin, B. (2017). Learning strategy in class management: A reflection from manado case. Earth and Environmental Science, 97 (1), 012-053.

Wong, J. O. (2020). A pandemic in 2020, Zoom and the arrival of the online educator. International Journal of TESOL Studies, 2(3), 82-99. 